\title{
PENGARUH MOTIVASI KERJA DAN KEDISIPLINAN TERHADAP KINERJA GURU SMP
}

\author{
Anis Syamsu Rizal \\ Program Studi Akuntansi, Universitas Pamulang, anissyamsurizal@gmail.com
}

\section{INFO ARTIKEL}

\section{Riwayat Artikel:}

Diterima : 05-01-2019

Disetujui : 14-01-2019

\section{Kata Kunci:}

Motivasi Kerja

Kedisiplinan

Kinerja Guru

\section{A. LATAR BELAKANG}

Ditemukan dalam berbagai penelitian bahwa guru merupakan faktor yang paling inti dalam memacu kualitas pendidikan, sehingga peningkatan kualitas profesi guru adalah sebuah keniscayaan. Pendidik yang
Abstrak: Permasalahan dalam penelitian ini adalah (1) adakah pengaruh motivasi kerja terhadap kinerja guru SMP? (2) Adakah pengaruh kedisiplinan terhadap kinerja guru SMP? (3) Adakah pengaruh motivasi kerja dan kedisiplinan terhadap kinerja guru SMP?. Tujuan dari penelitian ini adalah sebagai berikut: (1) Untuk mengetahui pengaruh motivasi kerja terhadap kinerja guru SMP. (2) Untuk mengetahui pengaruh kedisiplinan terhadap kinerja guru SMP. (3) Untuk mengetahui pengaruh motivasi kerja dan kedisiplinan terhadap kinerja guru SMP. Berdasarkan hasil penelitian, dapat disimpulkan sebagai berikut: (1) terdapat pengaruh motivasi kerja terhadap kinerja guru SMP. Motivasi kerja berpengaruh positif dan signifikan terhadap kinerja guru SMP sebesar 46,4\%. (2) terdapat pengaruh kedisiplinan terhadap kinerja guru SMP. Kedisiplinan berpengaruh positif dan signifikan terhadap kinerja guru SMP sebesar 21,4\%, (3) terdapat pengaruh motivasi kerja dan kedisiplinan terhadap kinerja guru SMP. Motivasi kerja dan kedisiplinan berpengaruh positif dan signifikan terhadap kinerja guru SMP sebesar 50\%.

Abstract. The problems in this study are (1) is there any influence of work motivation on the performance of junior high school teachers? (2) Is there influence on discipline on the performance of junior high school teachers? (3) Is there influence on work motivation and discipline on the performance of junior high school teachers? The objectives of this study are as follows: (1) To determine the effect of work motivation on the performance of junior high school teachers. (2) To determine the effect of discipline on the performance of junior high school teachers. (3) To determine the effect of work motivation and discipline on the performance of junior high school teachers. Based on the results of the study, it can be concluded as follows: (1) there is an influence of work motivation on the performance of junior high school teachers. Work motivation has a positive and significant effect on the performance of junior high school teachers by $46.4 \%$. (2) there is an influence of discipline on the performance of junior high school teachers. Discipline has a positive and significant effect on the performance of junior high school teachers at 21.4\%, (3) there is an influence of work motivation and discipline on the performance of junior high school teachers. Work motivation and discipline have a positive and significant effect on the performance of junior high school teachers by $50 \%$. profesional memiliki seperangkat kompetensi yang dipersyaratkan untuk menopang tugas dan fungsinya sebagai pendidik. Pendidik profesional tidak hanya sekedar menguasai bidang ilmu, bahan ajar, dan metode, tapi juga harus mampu memotivasi peserta didik, memiliki kecakapan yang tinggi, dan berwawasan luas. 
16|Jurnal Ulul Albab | Vol.23, No.1, Januari 2019, hal 15-22 Sehubungan dengan itu, kompetensi guru ini telah dipersyaratkan oleh peraturan pemerintah No. 19 Tahun 2005 pasal 28 ayat (3) yang meliputi kompetensi pedagogik, kompetensi kepribadian, kompetensi profesional, dan kompetensi sosial (Suryadi, 2014: 88).

Profesi guru menurut Suyanto (2013: 8) sangat identik dengan peran mendidik seperti membimbing, membina, mengasuh ataupun mengajar. Ibaratnya sebuah lukisan yang akan dipelajari oleh anak didiknya. Baik buruk hasil lukisan tersebut tergantung dari contoh yang diberikan sang guru, sebagai sosok yang digugu dan ditiru. Melihat peran tersebut, sudah menjadi kemutlakan bahwa guru harus memiliki integritas dan kepribadian yang baik dan benar. Hal ini sangat mendasar karena tugas guru bukan hanya mengajar tetapi juga menanamkan nilai-nilai dasar pengembangan karakter peserta didik.

Menurut Supardi (2014: 19) kinerja guru merupakan kemampuan dan keberhasilan guru dalam melaksanakan tugas-tugas pembelajaran. Kinerja guru dipengaruhi oleh beberapa faktor, faktor-faktor yang mempengaruhi kinerja antara lain: (1) sikap mental (motivasi kerja, disiplin kerja, etika kerja), (2) pendidikan, (3) ketrampilan, (4) manajemen kepemimpinan, (5) tingkat penghasilan, (6) gaji dan kesehatan, (7) jaminan sosial, (8) iklim kerja, (9) sarana prasarana, (10) teknologi, (11) kesempatan berprestasi.

Pencapaian tujuan jangka panjang maupun pendek pada setiap organisasi sekolah tidaklah mudah, karena untuk melaksanakannya tidak terlepas dari masalah yang pada akhirnya dapat menghambat organisasi sekolah tersebut. Tujuan yang diinginkan setiap organisasi sekolah pada umumnya yaitu sumber daya manusia yang produktif (productive human resourcers) yang dapat menciptakan tingkat kinerja yang tinggi. Tidak tercapainya tujuan suatu organisasi sekolah disebabkan sekolah tersebut memiliki motivasi kerja yang sangat rendah yang mempengaruhi lemahnya kinerja para pegawainya. Pemerintah selama ini menurut Subagyo (2013: 15) telah mengeluarkan biaya besar untuk menyelenggarakan pendidikan. Sudah sewajarnya bila biaya investsi itu ada imbal balik, yaitu berupa pendidikan bermutu. Pendidikan sendiri merupakan investasi dalam rangka meningkatkan mutu sumber daya manusia, meningkatkan daya saing bangsa, mendukung kemajuan dan kemakmuran bangsa.

Sumber daya manusia dengan kualitas baik dan memiliki kinerja yang tinggi, akan memudahkan tercapainya tujuan sekolah. Oleh karena itu, pihak sekolah perlu memikirkan sistem yang dapat meningkatkan kinerja guru. Antara lain pemberian motivasi terhadap guru, dan bagaimana cara memberi motivasi kepada guru agar dapat membangkitkan semangat dan dorongan untuk melaksanakan tugas secara optimal, adalah hal yang perlu dipikirkan. Apabila dalam pemberian motivasi kepada para guru kurang efektif dan tidak adil maka hal tersebut akan berdampak langsung terhadap kinerja guru. Hal ini juga langsung dapat terlihat dan dirasakan oleh para peserta didik maupun pengguna jasa guru tersebut.

Kondisi kinerja guru SMP di Kecamatan Bantarbolang dalam berbagai hal masih banyak yang belum menunjukkan kinerja yang baik. Pada umumnya kurang baiknya kinerja dari para guru SMP di Kecamatan Bantarbolang berhubungan dengan kurang siapnya guru menyusun perangkat kegiatan belajar mengajar (KBM), terlambat memberikan ulangan dan tingkat kehadiran yang rendah.

Selain peningkatan ketidakhadiran guru di sekolah, hasil observasi awal menunjukkan bahwa guru SMP di Kecamatan Bantarbolang dalam melaksanakan pembelajaran dengan metode yang kurang sesuai dengan materi pelajaran yang diberikan kepada siswa dan sering menggunakan metode ceramah sekalipun materinya membutuhkan metode demonstrasi. Dalam membina hubungan dengan peserta didik, guru SMP di Kecamatan Bantarbolang kebanyakan menerapkan hubungan atasan dan bawahan, bukan sebagai sahabat dan orang tua siswa. Selain itu, guru SMP di Kecamatan Bantarbolang jarang melaksanakan remedial jika ada siswa yang belum mencapai nilai KKM.

Penurunan kinerja guru SMP di Kecamatan Bantarbolang secara langsung maupun tidak langsung mengakibatkan terjadinya penurunan prestasi belajar siswa. Berdasarkan hasil wawancara dengan Pengawas SMP Kecamatan Bantarbolang pada hari Kamis, tanggal 7 Nopember 2014, hasil Ujian Nasional (UN) Tahun 2014, enam SMP di Kecamatan Bantarbolang Kabupaten Pemalang mendapatkan nilai rata-rata Ujian Nasional untuk empat mata pelajaran adalah 19,18 dan SMP di Kecamatan Bantarbolang berada pada peringkat 7 dari 14 Kecamatan yang ada di Kabupaten Pemalang. Walaupun SMP Negeri 1 Bantarbolang masuk sepuluh besar nilai rata-rata tertinggi di Kabupaten Pemalang, akan tetapi lima SMP lainnya belum dapat bersaing dengan SMP Negeri 1 Bantarbolang. Rata-rata nilai Ujian Nasional (UN) SMP di Kecamatan Bantarbolang mengalami penurunan setiap tahunnya baik SMP Negeri maupun SMP Swasta.

Kinerja guru menurut Supardi (2014: 54) merupakan kemampuan seorang guru dalam melaksanakan tugas pembelajaran di madrasah dan bertanggung jawab atas peserta didik di bawah bimbingannya dengan meningkatkan prestasi belajar peserta didik. Oleh karena itu, kinerja guru itu dapat diartikan sebagai suatu kondisi yang menunjukkan kemampuan seorang guru dalam menjalankan tugasnya di madrasah serta menggambarkan adanya suatu perbuatan ang ditampilkan guru dalam atau selama melakukan aktivitas pembelajaran.

Kinerja guru juga dapat ditunjukkan dari seberapa besar kompetensi-kompetensi yang dipersyaratkan dipenuhi. Kompetensi tersebut meliputi: kompetensi pedagogik, kompetensi kepribadian, kompetensi sosial dan kompetensi profesional (Undang-Undang No. 14 Tahun 2005 tentang Guru dan Dosen Pasal 10).

Galton dan Simon (1994: 15-17) memandang bahwa kinerja atau "performance" merupakan hasil interaksi atau berfungsinya unsure-unsur motivasi, kemampuan, dan persepsi pada diri seseorang. Sedangkan aspekaspek yang dapat dinilai dari kinerja seorang guru dalam suatu organisasi menurut Riva'i (2004: 324) dikelompokkan menjadi tiga, yaitu kemampuan teknik, kemampuan konseptual, dan kemampuan hubungan interpersonal: (1) Kemampuan teknik yaitu kemampuan menggunakan pengetahuan, metode, teknik, dan peralatan yang dipergunakan untuk melaksanakan tugas serta pengalaman dan pelatihan yang telah diperoleh. (2) Kemampuan konseptual yaitu kemampuan untuk memahami kompleksitas organisasi dan penyesuaian bidang gerak dari unit-unit operasional. (3) Kemampuan hubungan interpersonal yaitu antara lain kemampuan 
untuk bekerja sama dengan orang lain, membawa guru melakukan negosiasi.

Berdasarkan kedua pendapat di atas, disimpulkan melalui pendapat Michel dalam Supardi (2014: 70) mengenai aspek yang dilihat dalam menilai kinerja individu (termasuk guru) mengemukakan indikator yang berkaitan dengan variabel kinerja guru meliputi: (a) kualitas kerja, (b) kecepatan/ketepatan guru, (c) inisiatif dalam kerja, (d) kemampuan kerja, dan (e) komunikasi.

(a) Kualitas kerja. Indikator kualitas kerja guru terdiri dari menguasai bahan pelajaran, mengelola proses belajar mengajar, mengelola kelas. (b) Kecepatan/ketepatan kerja. Indikator kecepatan/ketepatan kerja guru berhubungan dengan penggunaan media atau sumber belajar, menguasai landasan pendidikan, merencanakan program pembelajaran. (c) Inisiatif dalam kerja. Indikator inisiatif dalam kerja guru terdiri dari memimpin kelas, mengelola interaksi belajar mengajar, melakukan penilaian hasil belajar siswa. (d) Kemampuan kerja. Indikator kemampuan kerja guru meliputi penggunaan berbagai metode dalam pembelajaran, memahami dan melaksanakan fungsi dan layanan bimbingan penyuluhan. (e) Komunikasi. Indikator komunikasi dalam hal ini dapat memahami dan menyelenggarkan administrasi sekolah, memahami dan dapat menafsirkan hasil-hasil penelitian untuk peningkatan kualitas pembelajaran.

Robbins (dalam Priansa, 2014: 201) mendefinisikan motivasi sebagai proses yang menunjukkan intensitas individu, arah, dan ketekunan dari upaya menuju pencapaian tujuan. Motivasi menurut Danim (2012: 23) dapat diartikan sebagai setiap daya gerak atau daya dorong yang muncul pada diri individu untuk secara sadar mengabdikan diri bagi pencapaian tujuan organisasi. Motivasi (Uno, 2013: 1) adalah dorongan dasar yang menggerakan seseorang bertingkah laku. Dorongan ini berada pada diri seseorang yang menggerakan untuk melakukan sesuatu yang sesuai dengan dorongan dalam dirinya. Oleh karena itu, perbuatan sesorang yang didasarkan atas motivasi tertentu mengandung tema sesuai dengan motivasi yang mendasarinya.

Menurut Bangun (2012: 316-321) teori motivasi mulai dikenal pada tahun 1950-an. Secara khusus, pada awalnya ada tiga teori motivasi antara lain, teori hierarki kebutuhan (the hierarchy of needs theory), teori dua faktor (two factor theory), dan teori X dan Y. Dari ketiga teori tersebut, teori yang digunakan dalam penelitian sekarang adalah teori hierarki kebutuhan dan teori dua faktor.

a. Teori Hierarki Kebutuhan Teori ini pertama sekali dikemukakan oleh Abraham Maslow, mungkin bisa dikatakan teori inilah yang paling populer bila dibanding dengan teori-teori motivasi lainnya. Teori ini menjelaskan bahwa setiap manusia mempunyai kebutuhan (need) yang munculnya sangat bergantung pada kepentingannya secara individu. Berdasarkan hal tersebut, maslow membagi kebutuhan manusia tersebut menjadi lima tingkatan, sehingga teori motivasi ini disebut sebagai "the five hierarchy need" mulai dari kebutuhan yang pertama sampai pada kebutuhan yang tertinggi. Adapun kelima tingkatan kebutuhan tersebut antara lain, kebutuhan fisiologis (psysiological need), kebutuhan rasa aman, (safety need), kebutuhan sosial (social need), kebutuhan harga diri (esteem need), dan kebutuhan untuk aktualisasi diri (need for self actualization).

b. Teori Dua Faktor. Teori dua faktor pertama sekali dikemukakan oleh Frederick Herzberg. Dalam teori ini dikemukakan bahwa, pada umumnya para karyawan baru cenderung untuk memusatkan perhatiannya pada pemuasan kebutuhan lebih rendah dalam pekerjaan pertama mereka, terutama keamanan.Berdasarkan hasil penelitiannya, Herzberg membagi dua faktor yang memengaruhi kerja seseorang dalam organisasi, antara lain faktor kepuasan dan ketidakpuasan. Faktor kepuasan atau motivator factor dikatakan sebagai faktor pemuas karena dapat memberikan kepuasan kerja seseorang dan juga dapat meningkatkan prestasi para pekerja, tetapi faktor ini tidak dapat menimbulkan ketidakpuasan bila hal itu tidak terpenuhi. Jadi faktor kepuasan bukanlah merupakan lawan dari faktor ketidakpuasan. Faktor kepuasan disebut juga sebagai motivasi intrinsik (intrinsic motivation). Faktor ketidakpuasan (dissatisfaction), biasa juga disebut sebagai hygiene factor atau faktor pemeliharaan merupakan faktor yang bersumber dari ketidakpuasan kerja. Faktor-faktor tersebut, antara lain, kebijakan dan administrasi perusahaan (company policy and administration), pengawasan (supervision), penggajian (salary), hubungan kerja (interpersonal relation), kondisi kerja (working condition), keamanan kerja (job security), dan status pekerjaan (job status). Faktor ketidakpuasan ini biasa juga disebut sebagai motivasi ekstrinsik (extrinsic motivation).

Menurut Siagian (2009: 305) disiplin merupakan tindakan manajemen untuk mendorong para anggota organisasi memenuhi tuntutan berbagai ketentuan (standar yang harus dipenuhi). Dengan perkataan lain, pendisiplinan pegawai adalah suatu bentuk pelatihan yang berusaha memperbaiki dan membentuk pengetahuan, sikap dan perilaku karyawan sehingga para karyawan tersebut secara sukarela berusaha bekerja secara kooperatif dengan para karyawan yang lain serta meningkatkan prestasi kerjanya. Kedisiplinan berarti peraturan yang dilakukan dengan ketegasan jiwa dengan penuh tanggung jawab. Sementara itu, menurut Simamora yang dikutip oleh Slamet (2007: 215-216), mendefinisikan disiplin sebagai bentuk pengendalian diri pekerja, dan pelaksanaan yang teratur dan menunjukkan kesungguhan tim kerja. Dengan demikian kedisiplinan merupakan fungsi operatif manajemen sumber daya manusia yang terpenting, karena semakin baik disiplin pekerja, maka akan semakin tinggi prestasi kerja yang dapat dicapainya. Tanpa disiplin pekerja yang baik, sulit buat organisasi untuk mencapai hasil yang optimal. Berdasarkan konteks tersebut dapat dikemukakan bahwa disiplin merupakan arahan untuk melatih dan membentuk seseorang melakukan sesuatu menjadi lebih baik. Oleh karena itu disiplin adalah suatu proses yang dapat menumbuhkan perasaan seseorang untuk mempertahankan dan meningkatkan tujuan organisasi secara obyektif, melalui kepatuhannya menjalankan peraturan organisasi.

Berdasarkan berbagai fenomena yang sudah terjadi pada SMP di Kecamatan Bantarbolang Kabupaten Pemalang seperti yang sudah disampaikan di atas serta berdasarkan uraian materi tentang kinerja guru yang dipengaruhi oleh motivasi kerja dan kedisiplinan, maka penelitian ini mengambil judul "Pengaruh Motivasi Kerja dan Kedisiplinan terhadap Kinerja Guru SMP di Kecamatan Bantarbolang Kabupaten Pemalang”. 
18|Jurnal Ulul Albab | Vol.23, No.1, Januari 2019, hal 15-22

Bertolak dari identifikasi masalah di atas, maka secara operasional permasalahan yang akan diteliti dapat dirumuskan sebagai berikut: (1) Adakah pengaruh motivasi kerja terhadap kinerja guru SMP di Kecamatan Bantarbolang Kabupaten Pemalang? (2) Adakah pengaruh kedisiplinan terhadap kinerja guru SMP di Kecamatan Bantarbolang Kabupaten Pemalang? (3) Adakah pengaruh motivasi kerja dan kedisiplinan terhadap kinerja guru SMP di Kecamatan Bantarbolang Kabupaten Pemalang?.

Hipotesis adalah jawaban sementara dari suatu penelitian yang perlu diuji kebenarannya, ada hipotesis deskriptif dan hipotesis statistik. Dari kajian teori diatas dan survei awal penulis, serta masalah yang ada, maka dapat ditentukan hipotesis penelitian yaitu:

Hipotesis deskriptif merupakan hipotesis yang berupa pernyataan kesimpulan sementara dari hasil kajian teori. Didapatkan hipotesis deskriptif sebagai berikut: (1) Ada pengaruh motivasi kerja terhadap kinerja guru SMP di Kecamatan Bantarbolang Kabupaten Pemalang, yang berarti Ha diterima dan Ho ditolak. (2) Ada pengaruh kedisiplinan terhadap kinerja guru SMP di Kecamatan Bantarbolang Kabupaten Pemalang, yang berarti Ha diterima dan Ho ditolak. (3) Ada pengaruh motivasi kerja dan kedisiplinan terhadap kinerja guru SMP di Kecamatan Bantarbolang Kabupaten Pemalang, yang berarti Ha diterima dan Ho ditolak.

Hipotesis Statistik adalah hipotesis yang didapat dari perhitungan statistik, yaitu hipotesis yang diajukan dalam analisis korelasi. Ho jika tidak ada korelasi dan ada syarat tertentu hipotesis diterima atau ditolak (Ha). Ada tiga hipotesis statistik pada penelitian ini yaitu: (a). (Ho), $\rho$ x1y $=$ o. ; . (Ha), $\rho$ x1y $\neq$ o. (b) (Ho), $\rho$ x2y $=0$. ; (Ha), $\rho$ x2y $\neq$ o. (c) (Ho), $\rho$ x12y = o. ; (Ha), $\rho$ x12y $\neq$ o.

\section{B. METODE PENELITIAN}

Tempat penelirian ini berada di Kecamatan Bantarbolang Kabupaten Pemalang Provinsi Jawa Tengah yang bertempat di SMP se-Kecamatan Bantarbolang, adapun waktu pelaksanaan penelitian selama empat bulan, terhitung dari Februari 2015 sampai dengan Mei 2015. Jenis penelitian ini adalah penelitian korelasional non eksperimental dengan menggunakan pendekatan kuantitatif karena data penelitian berupa angka-angka. Sedangkan penelitian ini menggunakan deskriptif karena kegiatannya meliputi pengumpulan data dalam rangka menguji hipotesis atau menjawab pertanyaan yang menyangkut keadaan pada waktu yang sedang berjalan. Rancangan penelitian ini disebut penelitian korelasi karena peneliti ingin mengetahui tingkat hubungan variabel-variabel yang berbeda dalam suatu populasi. Dalam penelitian ini untuk mencari pengaruh motivasi kerja dan kedisiplinan terhadap kinerja guru SMP di Kecamatan Bantarbolang Kabupaten Pemalang.

Populasi menurut Sukardi (2008: 53) adalah semua anggota kelompok manusia, binatang, peristiwa, atau benda yang tinggal bersama dalam satu tempat dan secara terencana menjadi target kesimpulan dari hasil akhir suatu penelitian. Populasi dapat berupa: guru, siswa, kurikulum, fasilitas, lembaga sekolah, hubungan sekolah dn masyarakat, karyawan perusahaan, jenis tanaman hutan, jenis padi, kegiatan marketing, hasil produksi dan sebagainya. Populasi dalam penelitian ini adalah seluruh guru SMP di Kecamatan Bantarbolang Kabupaten Pemalang. Target populasi adalah seluruh guru Pegawai Negeri Sipil (PNS) yang bertugas di 6 (enam) SMP di Kecamatan Bantarbolang yang berjumlah 220 orang. Di Bantarbolang terdapat 4 (empat) SMP yang berstatus negeri dan 2 (dua) SMP yang berstatus swasta dengan jumlah guru untuk masing-masing sekolah berbeda.

Maman, dkk (2011: 129) mengemukakan sampel adalah bagian kecil dari anggota populasi yang diambil menurut prosedur tertentu sehingga dapat mewakili populasinya. Penentuan ukuran sampel dalam penelitian ini menggunakan teori yang dikembangkan oleh Issac dan Michael dengan menggunakan pendekatan statistik. Dengan perhitungan sampel didasarkan atas kesalahan $5 \%$, jadi sampel yang diperoleh memiliki tingkat kepercayaan 95\% terhadap populasi (Sugiyono, 2009: 126-128). Bila terdapat populasi guru SMP di Kecamatan Bantarbolang sebanyak 220 orang, maka sampel yang didapat adalah 135 orang.

Pengumpulan data dalam penelitian ini memakai kuesioner yang merupakan teknik pengumpulan data yang dilakukan dengan cara memberi seperangkat pertanyaan atau pertanyaan tertulis kepada responden untuk dijawab (Sugiyono, 2009: 199). Teknik lain yang digunakan adalah dokumentasi untuk mengumpulkan data yang diperoleh melalui studi pustaka, literatur, surat kabar dan sebagainya.

Kuesioner dimaksudkan untuk mencari data primer tentang motivasi kerja kerja, kedisiplinan guru dan kinerja guru. Wawancara dengan kepala sekolah, guru dan karyawan di lingkungan obyek penelitian dimaksudkan untuk mengumpulkan data yang tidak diperoleh oleh data hasil kuesioner sedangkan observasi dilakukan untuk mengamati secara spesifik perilaku dari variabel yang sedang diteliti. Observasi juga dilakukan dalam upaya mendapatkan data-data umum lainnya tentang organisasi yang diteliti.

Teknik analisis data dalam penelitian ini menggunakan teknik analisis korelasi sederhana dan regresi berganda (multiple regression analysis) dengan bantuan program SPSS versi 16.0. Adapun tahap-tahap pelaksanaan analisis meliputi : (1) analisis deskriptif, (2) uji persyaratan analisis dan (3) uji hipotesis.

Analisis deskriptif dimaksudkan untuk mendapatkan gambaran penyebaran hasil penelitian masing-masing variabel secara kategorial. Deskripsi yang dimaksud mengenai kondisi nyata pengaruh motivasi kerja (X1) dan kedisiplinan (X2) terhadap kinerja guru (Y) dengan cara menghitung rata-rata masing-masing variabel penelitian.

Uji persyaratan analisis dilakukan dengan tujuan untuk mengetahui apakah data yang dikumpulkan memenuhi persyaratan untuk dianalisis dengan teknik 
yang telah direncanakan. Untuk menghitung korelasi dibutuhkan persyaratan hubungan variabel $\mathrm{X}$ dengan $\mathrm{Y}$ harus linier dan berdistribusi normal. Anggapan populasi berdistribusi normal perlu dicek agar langkahlangkah selanjutnya dapat dipertanggungjawabkan. Uji persyaratan analisis dilakukan dengan tujuan untuk mengetahui apakah data yang dikumpulkan memenuhi persyaratan untuk dianalisis dengan teknik yang telah direncanakan. Untuk menghitung korelasi dibutuhkan persyaratan hubungan variabel $\mathrm{X}$ dengan $\mathrm{Y}$ harus linier dan berdistribusi normal. Anggapan populasi berdistribusi normal perlu dicek agar langkah-langkah selanjutnya dapat dipertanggungjawabkan.

Uji hipotesis dilakukan dengan dua cara, yaitu uji analisis regresi sederhana dan berganda. getahui pengaruh masing-masing variabel prediktor yaitu motivasi kerja (X1), kedisiplinan (X2), terhadap kinerja guru $(\mathrm{Y})$ dengan menggunakan persamaan regresi yaitu:

$\mathrm{Y}=\mathrm{a}+\mathrm{bX}$

Keterangan:

$\mathrm{Y}=$ nilai yang diprediksi

$\mathrm{X}=$ nilai variabel prediktor

$\mathrm{a}=$ bilangan konstan

$\mathrm{b}=$ bilangan koefisien prediktor

b. Analisis Regresi Berganda

Uji analisis regresi berganda bertujuan untuk meramalkan nilai pengaruh dua atau lebih variabel predictor terhadap satu variabel kriterium, dengan menggunakan rumus persamaan regresi:

\section{Keterangan:}

$\mathrm{Y}=$ nilai yang diprediksi

$\mathrm{X}=$ nilai variabel prediktor

$\mathrm{a}=$ bilangan konstan

$\mathrm{b}=$ bilangan koefisien prediktor

Untuk pengujian hipotesis menggunakan bantuan software computer program SPSS versi 16.

\section{HASIL DAN PEMBAHASAN}

Analisis deskripsi digunakan untuk mengetahui gambaran tentang jawaban responden terhadap keuesioner dari angket penelitian ketiga variabel. Jawaban responden dapat mengidentifikasikan kategori setiap variabel dan mengidentifikasikan ketegori setiap indikator pada masing-masing variabel. Adapun deskripsi atas jawaban responden terhadap kuesioner ketiga variabel dapat dijelaskan sebagai berikut:

Variabel kinerja guru memiliki jumlah item 35 soal dengan jumlah yang valid sebanyak 31 butir soal dan 4 soal dinyatakan tidak valid. Berdasarkan hal tersebut, maka 4 soal tidak digunakan, variabel kinerja guru menggunakan 31 butir soal yang valid untuk dijadikan instrumen penelitian. Skor tertinggi tiap item adalah 5 dan skor terendah tiap item adalah 1 dengan jumlah responden sebanyak 135 orang. Hal ini berarti bahwa skor mutu sekolah tertinggi sebesar 20925 dan skor terendah sebesar 4185 .

Dari 32 butir pernyataan instrumen motivasi kerja sebanyak 25 valid, sedangkan 7 butir pernyataan tidak valid. Skor tertinggi tiap item adalah 5 dan skor terendah tiap item adalah 1 dengan jumlah responden sebanyak 135 orang. Hal ini berarti bahwa skor motivasi kerja tertinggi sebesar 16875 dan skor terendah sebesar 3375 .

Variabel kedisiplinan memiliki jumlah item 32 soal dengan jumlah yang valid sebanyak 26 butir soal dan 5 soal dinyatakan tidak valid. Skor tertinggi tiap item adalah 5 dan skor terendah tiap item adalah 1 dengan jumlah responden sebanyak 135 orang. Hal ini berarti bahwa skor kedisiplinan tertinggi sebesar 17550 dan skor terendah sebesar 3510.

Analisis regresi sederhana digunakan untuk memprediksi atau menguji pengaruh atau variabel $\mathrm{X}_{1}$ terhadap Y, dan $\mathrm{X}_{2}$ terhadap Y. Bila skor variabel $\mathrm{X}_{1}$ dan $\mathrm{X}_{2}$ dikehatui maka skor variabel $\mathrm{Y}$ dapat diprediksi besarnya. Analisis regresi juga dapat dilakukan untuk mengetahui linearitas variabel terikat dengan variabel bebasnya.

Hasil analisis statistik regresi pengaruh Motivasi Kerja $\left(\mathrm{X}_{1}\right)$ terhadap Kinerja Guru $(\mathrm{Y})$ :

\begin{tabular}{|c|c|c|c|c|c|c|}
\hline \multicolumn{7}{|c|}{ ANOVA $^{b}$} \\
\hline \multicolumn{2}{|c|}{ Model } & $\begin{array}{l}\text { Sum of } \\
\text { Squares }\end{array}$ & df & Mean Square & $\mathrm{F}$ & Sig. \\
\hline \multirow[t]{3}{*}{1} & Regression & 13380.322 & 1 & 13380.322 & 114.957 & $.000^{\mathrm{a}}$ \\
\hline & Residual & 15480.448 & 133 & 116.394 & & \\
\hline & Total & 28860.770 & 134 & & & \\
\hline
\end{tabular}

a. Predictors: (Constant), MOTIVASI KERJA

b. Dependent Variable: KINERJA GURU

Berdasarkan hasil uji Anova pada Tabel di atas diperoleh nilai $\mathrm{F}$ hitung sebesar 114,957 dan probabilitas (sig.) sebesar 0,000 < 0,05 yang berarti Ho ditolak. Artinya bahwa motivasi kerja berpengaruh signifikan terhadap kinerja guru.

\begin{tabular}{|c|c|c|c|c|c|c|}
\hline \multicolumn{7}{|c|}{ Coefficients $^{\mathrm{a}}$} \\
\hline \multirow[b]{2}{*}{ Model } & & \multicolumn{2}{|c|}{ Unstandardized Coefficients } & $\begin{array}{l}\text { Standardized } \\
\text { Coefficients }\end{array}$ & \multirow[b]{2}{*}{$t$} & \multirow[b]{2}{*}{ Sig. } \\
\hline & & B & Std. Error & Beta & & \\
\hline 1 & (Constant) & 47.756 & 5.365 & & 8.901 & .000 \\
\hline & MOTIVASI KERJA & .620 & .058 & .681 & 10.722 & .000 \\
\hline
\end{tabular}

Berdasarkan Tabel di atas terlihat persamaan regresi pengaruh motivasi kerja $\left(\mathrm{X}_{1}\right)$ terhadap Kinerja Guru $(\mathrm{Y}): \mathrm{Y}=47,756+0,620 \mathrm{X}_{1}$. Persamaan regresi tersebut dapat dijelaskan bahwa kinerja guru dipengaruhi oleh fluktuasi kenaikan dan penurunan motivasi kerja, dengan skor fluktuasi o, 620 .

Dasar pengambilan keputusan/ hipotesis: 1) Ho: Tidak ada pengaruh yang nyata (signifikan) variabel motivasi kerja $\left(\mathrm{X}_{1}\right)$ terhadap Kinerja Guru $(\mathrm{Y})$.

Dari output di atas dapat dikethui nilai $t$ hitung $=$ 10,722 dengan nilai signifikansi 0,000 < 0,05, maka Ho ditolak dan $\mathrm{H}_{1}$ diterima, yang berarti ada pengaruh yang nyata (signifikan) variabel motivasi kerja $\left(\mathrm{X}_{1}\right)$ terhadap Kinerja Guru (Y).

\begin{tabular}{|c|c|r|r|r|}
\multicolumn{5}{c|}{ Model Summary } \\
\hline Model & $\mathrm{R}$ & $\mathrm{R}$ Square & $\begin{array}{c}\text { Adjusted R } \\
\text { Square }\end{array}$ & $\begin{array}{c}\text { Std. Error of } \\
\text { the Estimate }\end{array}$ \\
\hline 1 & $.681^{\mathrm{a}}$ & .464 & .460 & 10.78862 \\
\hline
\end{tabular}

a. Predictors: (Constant), MOTIVASI KERJA

Output pada Tabel di atas menjelaskan besarnya nilai korelasi/hubungan (r) yaitu o,681 dan dijelaskan besarnya persentase pengaruh variabel Motivasi Kerja $\left(\mathrm{X}_{1}\right)$ terhadap Kinerja Guru $(\mathrm{Y})$ yang disebut koefisien determinasi yang merupakan hasil dari $\mathrm{R}^{2}$. 
20|Jurnal Ulul Albab | Vol.23, No.1, Januari 2019, hal 15-22

Output tersebut menunjukkan koefien determinasi $\left(\mathrm{R}^{2}\right)$ sebesar 0,464 yang mengandung pengertian bahwa pengaruh motivasi kerja terhadap Kinerja Guru (Y) adalah sebesar 46,4\%, sedangkan yang dipengaruhi oleh variabel lain sebesar 53,6\%. Data menunjukkan motivasi kerja berpengaruh terhadap kinerja guru. Jadi hipotesis yang menyatakan motivasi kerja berpengaruh secara signifikan terhadap kinerja guru terbukti. Variabel lain yang mempengaruhi kinerja guru teridentifikasi adalah variable X2 yaitu kedisiplinan guru, selain itu sarana dan prasarana penunjang kelancaran proses belajar mengajar juga mempengaruhi kinerja guru, kepemimpinan kepala sekolah juga menjadi salah satu variabel lain yang mempengaruhi kinerja guru.

Hasil analisis statistik regresi pengaruh Kedisiplinan $\left(\mathrm{X}_{2}\right)$ terhadap Kinerja Guru (Y):

$$
\text { ANOVA }^{\text {b }}
$$

\begin{tabular}{|c|c|c|c|c|c|c|}
\hline Mode & & $\begin{array}{l}\text { Sum of } \\
\text { Squares }\end{array}$ & $\mathrm{df}$ & Mean Square & $\mathrm{F}$ & Sig. \\
\hline \multirow[t]{3}{*}{1} & Regression & 6189.160 & 1 & 6189.160 & 36.308 & $.000^{\mathrm{a}}$ \\
\hline & Residual & 22671.611 & 133 & 170.463 & & \\
\hline & Total & 28860.770 & 134 & & & \\
\hline
\end{tabular}

a. Predictors: (Constant), KEDISIPLINAN

b. Dependent Variable: KINERJA GURU

Berdasarkan hasil uji Anova pada Tabel di atas nilai F hitung sebesar 36,308 dan probabilitas (sig.) sebesar 0,000 < 0,05 yang berarti Ho ditolak. Artinya bahwa kedisiplinan berpengaruh signifikan terhadap kinerja guru.

Coefficients $^{\mathrm{a}}$

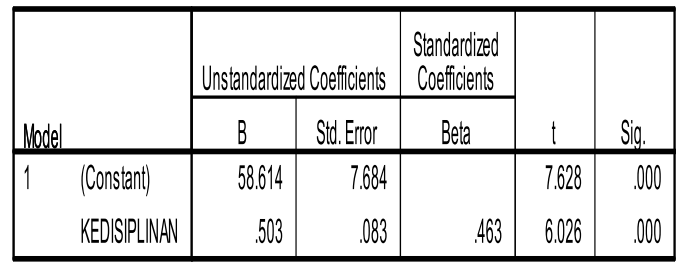

a. Dependent Variable: KNERJAGURU

Berdasarkan Tabel di atas persamaan regresi pengaruh Kedisiplinan $\left(\mathrm{X}_{2}\right)$ terhadap Kinerja Guru (Y): $\mathrm{Y}$ $=58,614+0,503 \mathrm{X}_{2}$ Persamaan regresi tersebut dapat dijelaskan bahwa kinerja guru dipengaruhi oleh fluktuasi kenaikan dan penurunan kedisiplinan, dengan skor fluktuasi 0,503 .

Dasar pengambilan keputusan/ hipotesis: 1) Ho: Tidak ada pengaruh yang nyata (signifikan) variabel Kedisiplinan $\left(\mathrm{X}_{2}\right)$ terhadap Kinerja Guru (Y).

Dari output di atas dapat dikethui nilai t hitung $=$ 6,026 dengan nilai signifikansi $0,000<0,05$, maka Ho ditolak dan $\mathrm{H} 1$ diterima, yang berarti ada pengaruh yang nyata (signifikan) variabel Kedisiplinan $\left(\mathrm{X}_{2}\right)$ terhadap Kinerja Guru (Y).

\begin{tabular}{|c|c|c|c|c|c|}
\hline \multicolumn{6}{|c|}{ Model Summary } \\
\hline Model & $R$ & R Square & $\begin{array}{c}\text { Adjusted R } \\
\text { Square }\end{array}$ & $\begin{array}{l}\text { Std. Error of } \\
\text { the Estimate }\end{array}$ & $\begin{array}{l}\text { Durbin- } \\
\text { Watson }\end{array}$ \\
\hline 1 & $.463^{\mathrm{a}}$ & .214 & .209 & 13.05616 & 1.708 \\
\hline
\end{tabular}

Output pada Tabel di atas dijelaskan besarnya nilai korelasi/hubungan (r) yaitu 0,463 dan dijelaskan besarnya persentase pengaruh variabel Kedisiplinan $\left(\mathrm{X}_{2}\right)$ terhadap Kinerja Guru (Y) yang disebut koefisien determinasi yang merupakan hasil dari $\mathrm{R}^{2}$.
Output tersebut menunjukkan koefisien determinasi $\left(\mathrm{R}^{2}\right)$ sebesar 0,214 yang mengandung pengertian bahwa pengaruh Kedisiplinan $\left(\mathrm{X}_{2}\right)$ terhadap Kinerja Guru (Y) adalah sebesar 21,4\%, sedangkan yang dipengaruhi oleh variabel lain sebesar 78,6\%. Data menunjukkan kedisiplinan berpengaruh terhadap kinerja guru. Jadi hipotesis yang menyatakan kedisiplinan berpengaruh secara signifikan terhadap kinerja guru terbukti. Variabel lain dari kedisiplinan yang memengaruhi kinerja guru teridentifikasi adalah variabel X1 yaitu motivasi kerja, selain itu ada variabel kompetensi yang dikuasai guru, supervisi akademik kepala sekolah, media dan metode pembelajaran yang digunakan guru juga memengaruhi kinerja guru.

Regresi linear berganda berguna untuk mencari pengaruh dua atau lebih variabel bebas (predictor) atau untuk mencari hubungan fungsional dua variabel predictor atau lebih terhadpa variabel kriteriumnya. Rumus yang digunakan sama seperti pada regresi sederhana namun, disesuaikan dengan jumlah variabel yang diteliti. Hasil analisis statistik terhadap kinerja guru dapat dilihat pada tabel berikut:

\section{Descriptive Statistics}

\begin{tabular}{|l|r|r|r|}
\hline & \multicolumn{1}{|c|}{ Mean } & Std. Deviation & \multicolumn{1}{c|}{$\mathrm{N}$} \\
\hline KINERJAGURU & 104.4148 & 14.67579 & 135 \\
MOTIVASI KERJA & 91.4444 & 16.12760 & 135 \\
KEDISIPLINAN & 91.0519 & 13.51081 & 135 \\
\hline
\end{tabular}

Tabel di atas menyajikan deskriptif data dari variabel motivasi kerja $\left(\mathrm{X}_{1}\right)$, variabel kedisiplinan $\left(\mathrm{X}_{2}\right)$, dan kinerja guru (Y) yang meliputi Mean (rata-rata), std. Deviation (standar deviasi) dan $\mathrm{N}=$ jumlah data.

\begin{tabular}{|c|c|c|c|c|c|c|}
\hline \multicolumn{7}{|c|}{ ANOVA $^{b}$} \\
\hline Model & & $\begin{array}{l}\text { Sum of } \\
\text { Squares }\end{array}$ & $d f$ & Mean Square & $F$ & Sig. \\
\hline 1 & Regression & 13380.322 & 1 & 13380.322 & 114.957 & $.000^{\mathrm{a}}$ \\
\hline & Residual & 15480.448 & 133 & 116.394 & & \\
\hline & Total & 28860.770 & 134 & & & \\
\hline
\end{tabular}

a. Predictors: (Constant), MOTIVASI KERJA

b. Dependent Variable: KINERJA GURU

Berdasarkan hasil uji Anova pada Tabel di atas diperoleh nilai F hitung sebesar 114,957 sedangkan nilai F-tabel pada taraf kepercayaan 0,05 sebesar 3,06. Jadi F-hitung lebih besar. Nilai probabilitas (sig.) sebesar o,ooo yang berarti lebih kecil dari taraf signifikan o,05, maka Ho ditolak berarti motivasi kerja $\left(\mathrm{X}_{1}\right)$ dan kedisiplinan $\left(\mathrm{X}_{2}\right)$ berpengaruh signifikan terhadap kinerja guru $(\mathrm{Y})$.

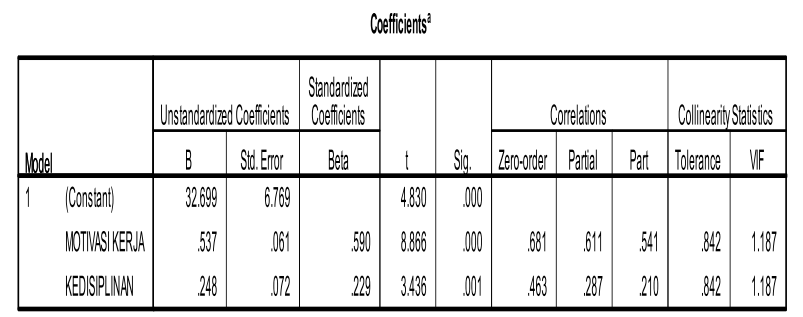

a. Depenendert Varidole:KNERUAGURU

Berdasarkan Tabel 4.9 persamaan regresi pengaruh motivasi $\left(\mathrm{X}_{1}\right)$ dan kedisiplinan $\left(\mathrm{X}_{2}\right)$ terhadap kinerja guru (Y): $\hat{\mathrm{Y}}=32,699+0,537 \mathrm{X}_{1}+0,248 \mathrm{X}_{2}$. Persamaan regresi tersebut dapat dijelaskan bahwa kinerja kerja dipengaruhi oleh fluktuasi kenaikan dan penurunan 
motivasi kerja dan kedisiplinan, dengan skor fluktuasi $\mathrm{X}_{1}$ sebesar 0,537 dan $\mathrm{X}_{2}$ sebesar 0,248.

Dari hasil pengujian regresi berganda diperoleh probabilitas (Sig.) motivasi kerja $\left(\mathrm{X}_{1}\right)$ sebesar $0,000<$ 0,05 sehingga Ho ditolak dan kedisiplinan $\left(\mathrm{X}_{2}\right)$ sebesar o,00o < 0,05 sehingga Ho ditolak. Jadi motivasi kerja dan kedisiplinan secara bersama-sama berpengaruh secara signifikan terhadap kinerja guru.

\section{Nodel Summary}

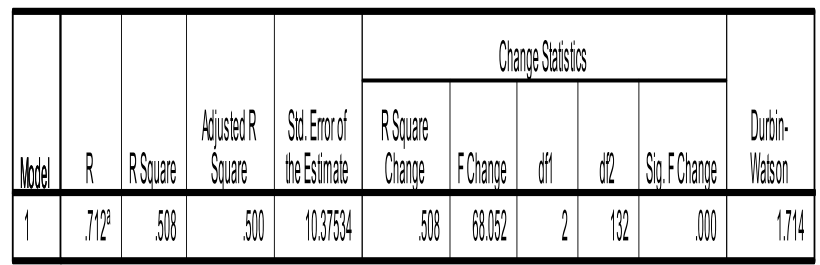

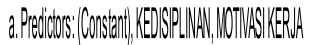

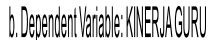

Tabel di atas menjelaskan bahwa dari hasil uji regresi berganda diperoleh nilai Adjusted $R$ Square sebesar 0,50 yang berarti motivasi kerja dan kedisiplinan berpengaruh sebesar 50\% terhadap kinerja guru , sisanya 50\% dipengaruhi oleh variabel lain yang dikaji dalam penelitian ini. Dengan demikian hipotesis yang menyatakan motivasi kerja dan kedisiplinan secara bersama-sama berpengaruh terhadap kinerja guru terbukti.

\section{KESIMPULAN DAN SARAN}

Berdasarkan hasil pengujian hipotesis dan analisis di atas dapat disimpulkan sebagai berikut:

1. Hasil uji hipotesis diperoleh $\mathrm{F}$ hitung $114,957>\mathrm{F}$ tabel 3,06 dengan signifikansi 0,000 $<0,05$, dan t hitung sebesar 10,722 dengan sifnigikansi $0,000<0,05$. Berarti terdapat pengaruh motivasi kerja terhadap kinerja guru SMP di Kecamatan Bantarbolang Kabupaten Pemalang dengan persamaan regresi $\hat{Y}=47,756+0,620 X 1$. Besarnya pengaruh motivasi kerja terhadap kinerja guru sebesar $46,4 \%$, sisanya sebesar $53,6 \%$ dipengaruh oleh faktor lain.

2. Hasil uji hipotesis diperoleh $\mathrm{F}$ hitung $36,308>\mathrm{F}$ tabel 3,06 dengan signifikansi 0,000 $<0,05$, dan t hitung sebesar 6,026 dengan sifnigikansi o,000 $<$ 0,05. Berarti terdapat pengaruh kedisiplinan terhadap kinerja guru SMP di Kecamatan Bantarbolang Kabupaten Pemalang dengan persamaan regresi $\hat{\mathrm{Y}}=58,614+0,503 \mathrm{X} 2$. Besarnya pengaruh kedisiplinan terhadap kinerja guru sebesar 21,4\%, sisanya sebesar $78,6 \%$ dipengaruh oleh faktor lain.

3. Hasil uji hipotesis diperoleh $\mathrm{F}$ hitung 114,957 > F tabel 3,06 dengan signifikansi $0,000<0,05$, dan thitung $\mathrm{X} 1=8,866$ dengan nilai signifikansi $0,000<0,05$ dan $t$ hitung $\mathrm{X} 2=3,436$ dengan nilai signifikansi $0,000<0,05$. Berarti terdapat pengaruh motivasi kerja dan kedisiplinan terhadap kinerja guru dengan persamaan regresi
Anis Syamsu Rizal, Pengaruh Motivasi Kerja...

$\hat{\mathrm{Y}}=32,699+0,537 \mathrm{X} 1+0,248 \mathrm{X} 2$. Besar pengaruh motivasi kerja dan kedisiplinan terhadap kinerja guru sebesar 50\%, sisanya sebesar 50\% dipengaruhi oleh faktor lain.

Berdasarkan hasil penelitian yang diperoleh, selanjutnya peneliti memberi saran-saran sebagai berikut: Dalam meningkatan motivasi kerja guru SMP di Kecamatan Bantarbolang Kabupaten Pemalang hendaknya guru, kepala sekolah dan pihak terkait lebih memperhatikan aspek-aspek yang menjadikan timbulnya motivasi kerja. Kepala sekolah SMP di Kecamatan Bantarbolang Kabupaten Pemalang diharapkan dapat meningkatkan pengakuan terhadap kinerja guru melalui pemberian penghargaan kepada guru yang berprestasi, sesama guru dan kepala sekolah diharapkan dapat membinan hubungan antar personal sehingga kenyamanan kerja dapat tercipta. Selain itu, Kepala Sekolah dan Pengawas SMP di Kecamatan Bantarbolang Kabupaten Pemalang hendaknya melaksanakan supervisi secara rutin dan berkesinambungan sebagai bagian dari peningkatan motivasi kerja.

\section{DAFTAR RUJUKAN}

[1].Bangun, Wilson. 2012. Manajemen Sumber Daya Manusia. Jakarta: Penerbit Erlangga.

[2]. Danim, Sudarwan. 2012. Motivasi Kepemimpinan dan Efektifitas Kelompok. Jakarta: PT Rineka Cipta. Cet. Ke-2.

[3]. Galton, Maurice dan Simon, Brian. 1994. Progress and Performance in The Primary Classroom. London: Routledge \& Kegan Paul.

[4]. Maman Abdurahman, Sambas Ali Muhidin, dan Ating Somantri. 2011. Dasar-Dasar Metode Statistika untuk Penelitian. Bandung: Pustaka Setia.

[5]. Priansa, Donni Juni. 2014. Perencanaan dan Pengembangan SDM. Bandung: Alfabeta.

[6]. Riva'i, V. 2004. Manajemen Sumber Daya Manusia untuk Pendidikan. Jakarta: Murai Kencana.

[7]. Siagian, Sondang P. 2009. Manajemen Sumber Daya Manusia. Jakarta: PT Bumi Aksara. Cetakan Ke-17.

[8]. Slamet, Achmad. 2007. Manajemen Sumber Daya Manusia. Semarang: UNNES Pres.

[9]. Sugiyono. 2009. Metode Penelitian Kuantitatif, Kualitatif dan R\&D. Bandung: Alfabeta.

[10].Sukardi. 2008. Metodologi Penelitian Pendidikan. Jakarta: PT Bumi Aksara. Cetakan Kelima. 
22 |Jurnal Ulul Albab | Vol.23, No.1, Januari 2019, hal 15-22

[11]. Supardi. 2014. Kinerja Guru. Jakarta: Rajawali Pers. Cetakan Ke-2.

[12].Suryadi, Ace. 2014. Pendidikan Indonesia Menuju 2025. Bandung: PT. Remaja Rosda Karya.

[13].Suyanto dan Asep Djihad. 2013. Calon Guru dan Guru Profesional. Yogyakarta: Multi Pressindo. Cetakan Ke-2.

[14].Undang-undang RI No. 14 Tahun 2005 tentang Guru dan Dosen. Diperbanyak oleh PB PGRI.

[15].Uno, Hamzah B., dan Nina Lamatenggo. 2012: Teori Kinerja dan Pengukurannya. Jakarta: Bumi Aksara. 